\title{
KEKUATAN MENGIKAT KLAUSUL EKSONERASI DALAM PERJANJIAN BAKU DIHUBUNGKAN DENGAN ASAS KEBEBASAN BERKONTRAK
}

\author{
Anwar Hidayat \\ Fakultas Ekonomi Bisnis Universitas Buana Perjuangan \\ Dedeanwarhidayat05@yahoo.co.id \\ DOI: https://doi.org/10.29313/sh.v16i2.5354
}

\begin{abstract}
ABSTRAK
Klausul eksonerasi dalam perkembangan globalisasi menimbulkan permasalahan karena cenderung merugikan hak-hak konsumen. Penelitian ini bertujuan untuk mengetahui pengertian klausul eksonerasi dalam perjanjian baku dan kekuatan mengikat klausul eksonerasi dalam perjanjian baku dihubungkan dengan asas kebebasan berkontrak Metode penelitian menggunakan pendekatan yuridis normatif dengan data sekunder dan studi kepustakaan serta menggunakan teknik analisis data secara kualitatif. Hasil penelitian Klausul eksonerasi adalah klausul yang dicantumkan dalam perjanjian baku/standar kontrak yang proses penyusunannya dibuat secara sepihak oleh pihak kreditur. Umumnya klausul eksonerasi yang ada pada perjanjian baku hanya mengatur kewajiban-kewajiban debitur dan meminimalisir kewajiban-kewajiban kreditur. Lahirnya perjanjian baku diakibatkan karena tuntutan globalisasi ekonomi dunia yang kemudian digunakan juga oleh para pelaku bisnis di Indonesia. Klausul eksonerasi dalam perjanjian baku bertentangan dengan asas kebebasan berkontrak yang bertanggung jawab, terlebih lagi jika ditinjau dari asas-asas dalam sistem hukum nasional, di mana akhirnya kepentingan masyarakatlah yang didahulukan. Di dalam perjanjian baku kedudukan kreditur dan debitur tidak seimbang. Posisi monopoli pihak kreditur membuka peluang luas baginya untuk menyalahgunakan kedudukannya. Pengusaha hanya mengatur hak-haknya dan tidak kewajibannya. Dari segi lain, perjanjian baku hanya memuat sejumlah kewajiban yang harus dipikul debitur.
\end{abstract}

Kata Kunci: Klausul Eksonerasi, Kekuatan Mengikat, Kebebasan Berkontrak.

\section{ABSTRACT}

The exoneration clause in the development raises problems because it tends to harm consumer rights. This study aims to determine the definition of exoneration clauses in the standard agreement and the binding strength of the exoneration clause in the standard agreement associated with the principle of freedom of contract. The research method uses a normative juridical approach with secondary data and literature studies and uses qualitative data analysis techniques. The results of the study The exoneration clause is a callus that is included in the standard agreement / standard contract for which the drafting process is made unilaterally by the creditor. Generally the exoneration clause in the standard agreement only regulates the obligations of the debtor and minimizes the 
obligations of the creditor. The birth of the standard agreement was caused by the demands of globalization of the world economy which was then used also by business people in Indonesia. The exoneration clause in the standard agreement contradicts the principle of freedom of contract which is responsible, even more so when viewed from the principles in the national legal system, where ultimatelythe interests of the community take precedence. In the standard agreement the position of creditors and debtors is not balanced. The creditor's monopoly position opens up a vast opportunity for him to abuse his position. Entrepreneurs only regulate their rights and not their obligations. In other terms, the standard agreement only contains a number of obligations that must be borne by the debtor.

Keywords: Exoneration Clause, Binding Strength, Contracting Freedom

\section{A. PENDAHULUAN}

\section{Latar Belakang Masalah}

Di era pembangunan dewasa ini kita menjumpai aneka produk barang/jasa yang dipasarkan kepada masyarakat. Pemasaran dilakukan oleh pengusaha melalui promosi dan periklanan. Selain itu globalisasi yang didukung oleh perkembangan ilmu pengetahuan dan teknologi komunikasi juga telah menawarkan aneka cara orang melakukan transaksi dan meningkatkan transaksi penjualan. Perkembangan ini memberikan manfaat kepada konsumen untuk memilih segala kebutuhannya dan kebebasan dalam memilih jenis dan kualitas barang/jasa. Namun di sisi lain perkembangan tersebut dapat mengakibatkan ketidakseimbangan dan lemahnya kedudukan konsumen di mata pelaku usaha, karena pelaku usaha dapat mengeksploitasi konsumen untuk kepentingan perdagangan dan meraih keuntungan yang sebesar- besarnya, jika kondisinya demikian diperlukan peranan pemerintah dalam melindungi kepentingan konsumen. ${ }^{1}$

Perlindungan konsumen adalah jaminan yang seharusnya didapatkan oleh para konsumen atas setiap produk yang dibeli dari produsen atau pelaku usaha. Saat ini ada para produsen yang tidak mementingkan kepentingan konsumennya karena sering kita jumpai pelanggaran-pelanggaran yang dilakukan oleh pihak produsen

\footnotetext{
${ }^{1}$ Firman Tarumantara, Kriminalisasi Klausula Baku dalam Perlindungan Konsumen, Jurnal Ilmu Hukum Litigasi, Vol. 10, No. 3, 2009, hlm 381
} 
kepada pihak konsumen. Undang undang tentang perlindungan konsumen ini memang telah di terbitkan namun dalam proses pelaksanaan atau aplikasi dari undang undang itu sendiri belum maksimal atau dengan kata lain peraturan yang ada dalam undang undang tidak sesuai dengan kenyataan. Dalam beberapa kasus banyak ditemukan pelanggaran- pelanggaran yang merugikan para konsumen yang tentunya berkaitan dengan tanggung jawab produsen (pelaku usaha) dalam tingkatan yang dianggap membahayakan kesehatan bahkan jiwa dari para konsumen. ${ }^{2}$

Perkembangan perekonomian, perdagangan, dan perindustrian yang kian hari kian meningkat telah memberikan kemanjaan yang luar biasa kepada konsumen karena ada beragam variasi produk barang dan jasa yang biasa dikonsumsi. Perkembangan globalisasi dan perdagangan besar didukung oleh teknologi informasi dan telekomunikasi yang memberikan ruang gerak yang sangat bebas dalam setiap transaksi perdagangan, sehingga barang/jasa yang dipasarkan bisa dengan mudah dikonsumsi. ${ }^{3}$

Permasalahan yang dihadapi konsumen tidak hanya sekedar bagaimana memilih barang, tetapi jauh lebih kompleks dari itu yang menyangkut pada kesadaran semua pihak, baik pengusaha, pemerintah maupun konsumen itu sendiri tentang pentingnya perlindungan konsumen. Pengusaha menyadari bahwa mereka harus menghargai hak- hak konsumen, memproduksi barang dan jasa yang berkualitas, aman untuk digunakan atau dikonsumsi, mengikuti standar yang berlaku, dengan harga yang sesuai. Pemerintah menyadari bahwa diperlukan undang-undang serta peraturan-peraturan di segala sektor yang berkaitan dengan berpindahnya barang dan jasa dari pengusaha ke konsumen. Pemerintah juga bertugas untuk mengawasi berjalannya peraturan serta undang-undang tersebut dengan baik.

Beberapa pelanggaran terhadap hak-hak masyarakat sebagai konsumen adalah konsumen terkadang tidak memiliki posisi yang setara dengan pelaku usaha

\footnotetext{
2 adi4rahayu.blogspot.com/2012/12/makalah-perlindungan-konsumen.html diakses tgl 05-04-14. Pkl 08.00

${ }^{3}$ Az Nasution, Hukum dan Konsumen, Pustaka Sinar Harapan, Jakarta, 1995, hlm 34.
} 
dan harus menyetujui kontrak yang telah dibuat secara sepihak oleh pelaku usaha dalam menjalankan bisnisnya. Adanya perjanjian baku yang di dalamnya terdapat klausula eksonerasi menjadikan pelaku usaha memiliki posisi yang lebih kuat dibandingkan dengan konsumen. Klausula eksonerasi bila ditinjau secara teoritis kiranya perlu dikaji kembali karena selain memberi manfaat terhadap transaksi bisnis juga memberikan dampak yang tidak baik bagi iklim perekonomian terutama menyangkut kepentingan- kepentingan debitur yang tidak bisa mengeluarkan kehendaknya secara leluasa karena harus mematuhi klausul-klausul yang sudah diatur dalam perjanjian baku.

\section{Identifikasi Masalah}

Artikel ini akan membahas Bagaimana pengertian klausul eksonerasi dalam perjanjian baku, dengan menguatkan hubungan melalui Bagaimana kekuatan mengikat klausul eksonerasi dalam perjanjian baku dihubungkan dengan asas kebebasan berkontrak yang bertanggung jawab dalam Kitab Undang-undang Hukum Perdata?

\section{Metode Penelitian}

Metode penelitian dalam penulisan ini menggunakan pendekatan yuridis normatif karena mengkaji peraturan perundang-undangan yang mengatur klausul eksonerasi dalam Undang-Undang Perlindungan Konsumen dengan menggunakan data sekunder melalui teknik studi kepustakaan dan dianalisis secara kualitatif.

\section{B. PEMBAHASAN}

\section{a. Pengertian Klausul Eksonerasi dalam Perjanjian Baku}

Perjanjian baku dialihbahasakan dari istilah yang dikenal dalam bahasa Belanda yaitu "standard contract" atau "standard voorwaarden". Di luar negeri belum terdapat keseragaman mengenai istilah yang dipergunakan untuk perjanjian baku. Kepustakaan Jerman menggunakan istilah "Allgermeine Geschafts Bedingun" standaard vertrag" hukum Inggris menyebut "standard contract” yang artinya perjanjian baku, baku berarti patokan, ukuran, acuan, jika bahasa hukum 
dibakukan, berarti bahasa hukum itu ditentukan ukurannya, patokannya standarnya, sehingga memiliki arti tetap yang dapat menjadi pegangan umum. ${ }^{4}$

Latar belakang tumbuhnya perjanjian baku karena keadaan sosial ekonomi. Perusahaan besar, dan perusahaan pemerintah mengadakan perjanjian kerjasama dalam suatu organisasi dan untuk kepentingan mereka ditentukan syarat-syarat secara sepihak. Pihak lawannya (wederparti) pada umumnya mempunyai kedudukan ekonomi lemah baik karena posisinya maupun karena ketidaktahuannya hanya menerima apa yang disodorkan. ${ }^{5}$

Dengan penggunaan perjanjian baku ini, maka pengusaha akan memperoleh efisiensi dalam pengeluaran biaya, tenaga dan waktu. ${ }^{6}$ Sehubungan dengan sifat massal dan kolektif, perjanjian baku vera bolger menamakannya sebagai "take it or leave contract" jika debitur menyetujui salah satu syarat-syarat, maka debitur mungkin hanya bersikap menerima atau tidak menerimanya sama sekali, kemungkinan untuk mengadakan perubahan itu sama sekali tidak ada. ${ }^{7}$

Beberapa ahli mencoba memberikan definisi mengenai klausul eksonerasi dan perjanjian baku. Rijken mengatakan bahwa klausul eksonerasi adalah klausul yang dicantumkan di dalam suatu perjanjian dengan mana satu pihak menghindarkan diri untuk menghindarkan diri dari kewajibannya dengan membayar ganti rugi seluruhnya atau terbatas yang terjadi karena ingkar janji atau perbuatan melawan hukum. ${ }^{8}$

Klausul eksonerasi/eksensi ini dapat terjadi atas kehendak satu pihak yang dituangkan dalam perjanjian secara individual atau secara massal, yang bersifat massal ini telah dipersiapkan terlebih dahulu dan diperbanyak dalam bentuk formulir yang dinamakan perjanjian baku. Hondius merumuskan perjanjian baku adalah konsep perjanjian tertulis yang disusun tanpa membicarakan isinya dan

\footnotetext{
${ }^{4}$ Mariam Darus Badrulzaman, Aneka Hukum Bisnis, Alumni, Bandung, 1994, hlm 46

${ }^{5}$ Ibid.

${ }^{6}$ Janus Sidabalok, Pengantar Hukum Ekonomi, Bina Media, Medan, 2000, hlm 99.

${ }^{7}$ Janus Sidabalok, Hukum Perlindungan Konsumen, PT Citra Aditya Bakti, 2010, hlm 13.

${ }^{8}$ Kelik Wardiono, Perjanjian Baku, Klausul Eksonerasi dan Konsumen, Ombak, 2014, hlm 18
} 
lazimnya dituangkan dalam sejumlah perjanjian tidak terbatas yang sifatnya tertentu. ${ }^{9}$

Uraian di atas menunjukkan bahwa perjanjian baku adalah perjanjian yang di dalamnya dibakukan syarat eksonerasi dan dituangkan dalam bentuk formulir. Jika seseorang pada suatu saat membuka rekening di bank atau mencuci pakaian di tukang laundry atau mengirimkan surat melalui penitipan kilat tanpa disadari seseorang tersebut mengikatkan diri pada perjanjian baku. Dari pegawai bank akan menerima perjanjian rekening koran, dari titipan kilat akan menerima tanda terima yang bersifat perjanjian baku. Formulir itu bermacam-macam bentuknya, ada yang panjang terdiri dari beberapa lembar kertas, ada yang hanya terdiri dari satu lembar kertas, ada pula yang lebih kecil dari itu, hurufnya dicetak kecil yang kadang-kadang diperlukan kaca mata untuk membacanya.

Sebagai contoh ada seseorang yang mengirimkan surat melalui pengusaha titipan kilat akan menerima surat tanda terima yang di halaman mukanya tercantum suatu uraian tentang jam penerimaan, alamat, pengirim, dan biaya titipan. Pada bagian akhir, dicantumkan syarat-syarat pengangkutan yang isinya antara lain mengatur batas- batas pertanggungjawaban pengusaha yaitu sebagai berikut: ${ }^{10}$

1. Titipan-titipan dianggap sah oleh pengusaha apabila pengirim sudah menerima lembaran asli surat tanda terima. Isi titipan tanggung jawab si pengirim sepenuhnya karena pengusaha menerima titipan ini dalam keadaan tertutup.

2. Titipan-titipan yang berisi uang tunai atau wesel, cek harap diperlihatkan kepada petugas kami, titipan golongan ini jika terjadi kehilangan dan sebagainya bukan tanggung jawab pengusaha

3. Titipan-titipan apabila sudah diterima pada alamat yang dituju, tidak lagi menjadi tanggung jawab pengusaha dan permintaan pengembalian surat

\footnotetext{
${ }^{9}$ Herlien Budinono, Asas Keseimbangan Bagi Perjanjian Indonesia, Citra Aditya Bakti, Bandung, 2013, hlm 84

${ }^{10}$ Subekti, Hukum Perjanjian, Intermasa, Bandung, 2001, hlm 73.
} 
tanda terima setelah tiga bulan terhitung tanggal pengiriman di luar tanggung jawab kami

4. Barang-barang cair, pecah atau barang yang mudah pecah/patah adalah tanggung jawab si pengirim sepenuhnya

5. Bilamana terjadi kehilangan atas titipan-titipan ini, penggantian maksimal adalah 10 kali dari biaya pengiriman yang tercantum dalam STT ini.

6. Bilamana terjadi kehilangan, kerusakan, kebakaran, dan sebagainya yang diakibatkan force majeure bukan tanggung jawab pengusaha dan pengusaha tidak bertanggung jawab atas kerugian apapun yang diakibatkan oleh kelambatan dalam pengangkutan

Pengirim dengan ini menerangkan bahwa keterangan yang dimuat dalam halaman ini adalah benar dan bahwa ia menerima syarat-syarat pengangkutan yang tertera pada halaman surat titipan. Pada masa yang akan datang, sebagai akibat dari pengaruh globalisasi perjanjian baku dengan bentuk formulir ini secara luas menguasai dunia bisnis di Indonesia.

Klausul eksonerasi yang tercantum dalam perjanjian baku sebenarnya dari sisi praktis memberikan banyak manfaat yaitu memberikan kemudahan dalam transaksi bisnis yang dilakukan oleh para pelaku usaha dan mitranya, tetapi apabila dilihat dari sisi kepentingan debitur, adanya klausul eksonerasi dalam perjanjian baku membatasi kebebasan debitur untuk menyatakan kehendaknya di dalam suatu perjanjian yang tertulis.

b. Klausul Eksonerasi Dalam Perjanjian Baku Dihubungkan Dengan Asas

Kebebasan Berkontrak yang Bertanggungjawab dalam Kitab Undangundang Hukum Perdata

Klausul eksonerasi/perjanjian baku dapat dibedakan dalam tiga jenis, yaitu sebagai berikut: ${ }^{11}$

1. Perjanjian baku sepihak adalah perjanjian yang isinya ditentukan oleh pihak yang kuat kedudukannya di dalam perjanjian itu. Pihak yang kuat di sini adalah pihak kreditur yang lazimnya mempunyai posisi ekonomi yang

\footnotetext{
${ }^{11}$ Mariam Darul Badruzaman, Op. Cit, hlm 49.
} 
kuat dibandingkan pihak debitur. Kedua pihak lazimnya terikat dalam organisasi, misalnya dalam perjanjian buruh kolektif.

2. Perjanjian baku yang ditetapkan oleh pemerintah ialah perjanjian baku yang mempunyai obyek hak atas tanah. Dalam bidang agraria, lihatlah misalnya formulir-formulir perjanjian yang sebagaimana yang diatur dalam SK Menteri Dalam Negeri tanggal 6 Agustus 1977 No 104/Dja/1977. Yang berupa antara lain akta jual beli, akta hipotek dan lainlain.

3. Perjanjian baku yang ditentukan di lingkungan notaris atau advokat terdapat perjanjian-perjanjian yang konsepnya sejak semula sudah disediakan untuk memenuhi permintaan dari anggota masyarakat yang akan meminta bantuan notaris atau advokat yang bersangkutan.

Berdasarkan keseluruhan jenis perjanjian baku ini dapat disimpulkan bahwa ciri-ciri meniadakan dan membatasi kewajiban salah satu pihak (kreditur) untuk membayar ganti rugi kepada debitur adalah sebagai berikut: ${ }^{12}$

1. Isinya ditetapkan secara sepihak oleh kreditur yang posisinya relatif lebih kuat daripada debitur

2. Debitur sama sekali tidak ikut menentukan isi perjanjian itu

3. Terdorong oleh kebutuhannya debitur sehingga debitur menerima perjanjian itu

4. Bentuknya tertulis

5. Dipersiapkan terlebih dahulu secara massal atau individual

Merupakan pertanyaan dalam hal ini adalah apakah klausul eksonerasi yang ada dalam perjanjian baku memenuhi syarat sahnya suatu perjanjian antara lain untuk memenuhi asas kebebasan berkontrak yang bertanggung jawab. Asas kebebasan berkontrak yang bertanggung jawab memiliki pengertian bahwa di dalam kebebasan terkandung "tanggung jawab". Di dalam hukum perjanjian nasional, asas kebebasan berkontrak yang bertanggung jawab yang mampu memelihara keseimbangan perlu dipelihara sebagai modal "pengembangan

${ }^{12}$ Ibid. 
kepribadian" untuk mencapai kesejahteraan dan kebahagiaan hidup lahir dan batin yang serasi, selaras, dan seimbang dengan kepentingan masyarakat. Dari uraian di atas dapat disimpulkan bahwa asas kebebasan berkontrak tidak mempunyai arti tidak terbatas, akan tetapi terbatas oleh tanggung jawab para pihak, sehingga kebebasan berkontrak sebagai asas diberi sifat asas kebebasan berkontrak yang bertanggung jawab. Asas ini mendukung adanya kedudukan yang seimbang diantara para pihak sehingga sebuah kontrak akan bersifat stabil dan memberikan keuntungan bagi kedua pihak. ${ }^{13}$

Pasal 1320 Kitab Undang-undang Hukum Perdata menentukan bahwa untuk sahnya suatu perjanjian diperlukan empat syarat, yaitu: ${ }^{14}$

1. Kesepakatan mereka yang mengikatkan dirinya

2. Kecakapan untuk membuat suatu perikatan

3. Suatu hal yang tertentu

4. Suatu sebab yang halal

Kesepakatan mereka yang mengikatkan diri adalah asas esensial dari hukum perjanjian. Asas ini dinamakan juga asas konsensualisme yang menentukan adanya raison d'entre het bestaanwaarde perjanjian. ${ }^{15}$ Di dalam hukum Inggris asas ini dikenal juga Anson berkata bahwa: ${ }^{16}$

"A promise more than a mere statement of intention, for it imports a willingness on the part of the promise to be bound to the person to whom it is made"

Dengan demikian, kita melihat bahwa asas kebebasan ini tidak hanya terdapat di dalam KUHPerdata akan tetapi bersifat universal. Asas konsensualisme yang terdapat di dalam Pasal 1320 Kuhperdata mengandung arti "kemauan" (will) para pihak untuk saling berprestasi, ada kemauan untuk saling mengikatkan diri. Kemauan ini mengakibatkan kepercayaan (vertrouwen)

\footnotetext{
13 Ibid, hlm 45.

${ }^{14}$ Richard Burton Simatupang, Aspek Hukum dalam Bisnis, Rineka Cipta, Jakarta, 1996, hlm 34-35.

${ }^{15}$ Amirizal, Hukum Bisnis Deregulasi dan Joint Venture di Indonesia Teori dan Praktik, Djambatan, Jakarta, 1996, hlm 33.

${ }_{16}$ Mariam Darul Badrulzaman, Op. Cit, hlm 51.
} 
bahwa perjanjian itu akan dipenuhi. Asas kepercayaan ini merupakan nilai etis yang bersumber pada moral. Manusia terhormat akan memelihara janjinya. ${ }^{17}$

Grotius mencari dasar konsensus itu di dalam hukum kodrat. Ia mengatakan bahwa pacta sunt servanda (janji itu mengikat). Seterusnya ia mengatakan lagi promisorum impledorum obligation (kita harus memenuhi janji kita). Asas konsensualisme ini mempunyai hubungan yang erat dengan asas kebebasan berkontrak dan asas kekuatan meningkat yang terdapat dalam Pasal 1338 ayat (1) Kuhperdata ketentuan ini berbunyi "Semua persetujuan yang dibuat secara sah berlaku sebagai undang-undang bagi mereka yang membuatnya"

Semua mengandung arti meliputi seluruh perjanjian baik yang namanya dikenal maupun yang tidak dikenal oleh undang-undang. asas kebebasan berkontrak berkaitan erat dengan isi perjanjian yaitu kebebasan menentukan "apa" dan dengan "siapa" perjanjian itu diadakan. Perjanjian yang dibuat sesuai dengan Pasal 1320 Kuhperdata ini mempunyai kekuatan mengikat.

Meninjau mengenai masalah "ada" dan "kekuatan mengikat" klausul eksonerasi dalam perjanjian baku maka secara teoritis yuridis perjanjian ini tidak memenuhi elemen-elemen yang dikehendaki oleh Pasal 1320 Jo 1338 ayat (1) Kuhperdata. Kita melihat bahwa perbedaan posisi para pihak ketika perjanjian baku diadakan tidak memberikan kesempatan pada debitur untuk mengadakan "real bargaining" dengan pengusaha (kreditur). Debitur tidak mempunyai kekuatan untuk mengutarakan kehendak dan kebebasan dalam menentukan isi perjanjian baku ini karena tidak memenuhi elemen-elemen yang dikehendaki Pasal 1320 Jo 1338 Kuhperdata dan akibatnya tidak ada.

Ada dua paham yang memberikan jawaban terhadap pertanyaan apakah perjanjian baku melanggar asas kebebasan berkontrak atau tidak. Sluitjer mengatakan, perjanjian baku ini bukan perjanjian, sebab kedudukan pengusaha di dalam perjanjian itu adalah seperti pembentuk undang-undang (legio

\footnotetext{
${ }^{17}$ Husni Syawali, Harumiati dan Ahmad Suja'i Abdullah, Hukum Perikatan, Tjempaka Offset, Bandung, 2010, hlm 76 .
} 
particuliere wetgever). ${ }^{18}$ Syarat- syarat yang ditentukan pengusaha di dalam perjanjian itu adalah undang-undang bukan perjanjian.

Pitlo mengatakannya sebagai perjanjian paksa (dwang contract) walaupun secara teoritis yuridis perjanjian baku ini tidak memenuhi ketentuan undang-undang dan oleh beberapa ahli hukum ditolak. Namun kenyataannya kebutuhan masyarakat berjalan dalam arah yang berlawanan dengan keinginan hukum. ${ }^{19}$

Stein mencoba memecahkan masalah ini dengan mengemukakan pendapat bahwa perjanjian baku dapat diterima sebagai perjanjian berdasarkan fiksi adanya kemauan dan kepercayaan (fictie van wil en vertrouwn) yang membangkitkan kepercayaan bahwa para pihak mengikatkan diri pada perjanjian itu. Jika debitur menerima dokumen perjanjian itu, berarti ia secara sukarela setuju pada isi perjanjian tersebut.

Asser Ruten mengatakan pula bahwa setiap orang yang menandatangani perjanjian, bertanggung jawab pada isi dan apa yang ditandatanganinya. Jika ada orang yang membubuhkan tanda tangan pada formulir perjanjian baku, tanda tangan itu akan membangkitkan kepercayaan bahwa yang bertandatangan mengetahui dan menghendaki isi formulir yang ditandatangani tidak mungkin seseorang menandatangani apa yang tidak diketahui isinya.

\section{PENUTUP}

Klausul eksonerasi adalah klausul yang dicantumkan dalam perjanjian baku/standar kontrak yang proses penyusunannya dibuat secara sepihak oleh pihak kreditur. Umumnya klausul eksonerasi yang ada pada perjanjian baku hanya mengatur kewajiban-kewajiban debitur dan meminimalisir kewajiban-kewajiban kreditur. Lahirnya perjanjian baku diakibatkan karena tuntutan globalisasi ekonomi dunia yang kemudian digunakan juga oleh para pelaku bisnis di Indonesia.

\footnotetext{
${ }^{18}$ M Syamsudin, Keadilan Substantif yang Terabaikan dalam Sengketa Sita Jaminan, Jurnal Yudisial, Vol. V, No 01, 2012, hlm 41.

${ }^{19}$ Ronny Bako, Hubungan Bank dan Nasabah Terhadap Produk Tabungan dan Deposito, PT Citra Aditya Bakti, Jakarta, 1995, hlm. 27.
} 
Klausul eksonerasi dalam perjanjian baku bertentangan dengan asas kebebasan berkontrak yang bertanggung jawab, terlebih lagi jika ditinjau dari asasasas dalam sistem hukum nasional, di mana akhirnya kepentingan masyarakatlah yang didahulukan. Di dalam perjanjian baku kedudukan kreditur dan debitur tidak seimbang. Posisi monopoli pihak kreditur membuka peluang luas baginya untuk menyalahgunakan kedudukannya. Pengusaha hanya mengatur hakhaknya dan tidak kewajibannya. Dari segi lain, perjanjian baku hanya memuat sejumlah kewajiban yang harus dipikul debitur.

Oleh karena itu tantangan yang dihadapi di masa yang akan datang adalah bagaimana caranya memberikan perlindungan kepada debitur, apakah kriteria yang dipergunakan untuk menertibkan klausul eksonerasi dalam perjanjian baku tersebut. Dalam hal ini yang dapat berperan adalah badan pembentuk undangundang, pemerintah, pengadilan, notaris dan konsultan hukum. Pembentuk undangundang disarankan untuk memikirkan pengaturan klausul eksonerasi dalam perjanjian baku, pemerintah harus melakukan pengawasan terhadap diberlakukannya klausul eksonerasi untuk menjamin kepentingan-kepentingan debitur.

Bagi para konsultan hukum dalam hal ini adalah memberikan nasihat hukum kepada para pihak tentang klausul eksonerasi yang terdapat di dalam suatu perjanjian yang diinginkan oleh para pihak dan menerangkan ketidakseimbangan diantara para pihak dan resiko yang dihadapi mereka. Notaris berkewajiban sesuai dengan kode etiknya untuk menanyakan kepada para pihak apakah mereka telah memahami klausul eksonerasi dalam hal klausul itu tercantum dalam perjanjian yang akan diadakan oleh para pihak. 


\section{DAFTAR ISI}

\section{A. Buku}

Az Nasution, Hukum dan Konsumen, Pustaka Sinar Harapan, Jakarta, 1995.

Amirizal, Hukum Bisnis Deregulasi dan Joint Venture di Indonesia Teori dan Praktik, Djambatan, Jakarta, 1996.

Herlien Budinono, Asas Keseimbangan Bagi Perjanjian Indonesia, Citra Aditya Bakti, Bandung, 2013.

Husni Syawali, Harumiati dan Ahmad Suja'i Abdullah, Hukum Perikatan, Tjempaka Offset, Bandung, 2010.

Janus Sidabalok, Pengantar Hukum Ekonomi, Bina Media, Medan, 2000.

, Hukum Perlindungan Konsumen, PT Citra Aditya Bakti, 2010. Kelik Wardiono, Perjanjian Baku, Klausul Eksonerasi dan Konsumen, Ombak, 2014

Richard Burton Simatupang, Aspek Hukum dalam Bisnis, Rineka Cipta, Jakarta, 1996.

Ronny Bako, Hubungan Bank dan Nasabah Terhadap Produk Tabungan dan Deposito, PT Citra Aditya Bakti, Jakarta, 1995.

Subekti, Hukum Perjanjian, Intermasa, Bandung, 2001.

\section{B. Jurnal/Makalah}

M Syamsudin, Keadilan Substantif yang Terabaikan dalam Sengketa Sita Jaminan, Jurnal Yudisial, Vol. V, No 01, 2012.

Firman Tarumantara, Kriminalisasi Klausula Baku dalam Perlindungan Konsumen, Jurnal Ilmu Hukum Litigasi, Vol. 10, No 3, 2009. 